\title{
First report of Fusarium oxysporum f. sp. lilii and F. proliferatum affecting Lilium crops in Spain
}

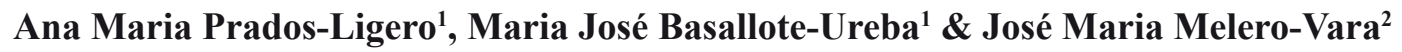 \\ ${ }^{1}$ Instituto Andaluz de Investigación y Formación Agraria, Pesquera, Alimentaria y de la Producción Ecológica (IFAPA), \\ Apdo 3092, 14080-Córdoba, Spain; ${ }^{2}$ Instituto de Agricultura Sostenible (IAS, CSIC), Apdo 4084, 14080 Córdoba, Spain, \\ e-mail: cs9mevaj@uco.es
}

Author for correspondence: José Maria Melero-Vara.

\begin{abstract}
Fusarium oxysporum f.sp. lilii and F. proliferatum were associated for the first time in Spain to leaf chlorosis, defoliation, necrotic spots on bulbs and roots, dwarfing and death of Oriental hybrids of Lilium plants, and artificial inoculations showed their pathogenicity to lily cv. Siberia.

Keywords: Basal rot, etiology, Koch's postulates, pathogenicity tests.

\section{RESUMO}

Primeiro relato de Fusarium oxysporum f. sp. lilii e $\boldsymbol{F}$. proliferatum causando doença na cultura de Lilium na Espanha A ocorrência de Fusarium oxysporum f. sp. lilii e F. proliferatum, causando clorose, redução de crescimento e morte das plantas em lírio foi relatada pela primeira vez, na Espanha. Os patógenos foram isolados dos dois principais híbridos cultivados: "Oriental e Asian". Palavras-chave: Etiologia, podridão do colo, postulados de Koch, teste de patogenicidade.
\end{abstract}

Dwarf and chlorotic Lilium plants were observed in spots in greenhouses of SW Spain. The affected Oriental lily plants showed defoliation of the abaxial part of the stem (Figure 1), and necrotic brown-black spots of bulbs, and support and absorbent roots. Similar symptoms have been described in Oriental and Asian hybrids of Lilium, and Easter lily (L. longiflorum Thunb.) by Bald et al. (1983). Fusarium isolates were obtained from stem and roots of Lilium plants of Oriental varieties Coloma, Tibet and Siberia. They were increased separately on sterile substrate (sand: corn meal, $9: 1 ; \mathrm{v} / \mathrm{v}$ ) during 15 days at $24^{\circ} \mathrm{C}$, and then mixed with uninfested soil $(1: 4, \mathrm{v} / \mathrm{v})$. Bulbs of the Oriental variety Siberia, susceptible to Fusarium oxysporum f. sp. lilii Imle were planted in this mixture and kept for 95 days at $25^{\circ} \mathrm{C}$ with a $12 \mathrm{~h}$ photoperiod. Evaluations of symptoms and severity were performed weekly according to a scale 1-5, where $1=$ asymptomatic plant, $2=10-49 \%$ of the plant with necrosis, $3=50-79 \%$ of the plant with necrosis, $4=80-90 \%$ of the plant with necrosis, $5=$ dead plant. At the end of the experiment, isolations from different parts of the stems of symptomatic plants were made on PDA and on V8-agar. All the isolates tested caused dwarfing, wilting and malformations of Lilium plants or prevented blooming, causing plant death since 60 days after bulb planting. Severity values of 4-5 were reached (Figure 2), and Fusarium isolates were recovered from all plants inoculated. Four out of the six Fusarium isolates tested were characterized as F. oxysporum whereas the other two were $F$. proliferatum (Matsush.) Nirenberg. This is the first report of $F$. oxysporum f. sp. lilii and $F$. proliferatum affecting Lilium crops in Spain. Both species were reported in the Netherlands (Löffler et al., 1995), and F. oxysporum was reported in Lilium crops of Italy, Poland and the USA.

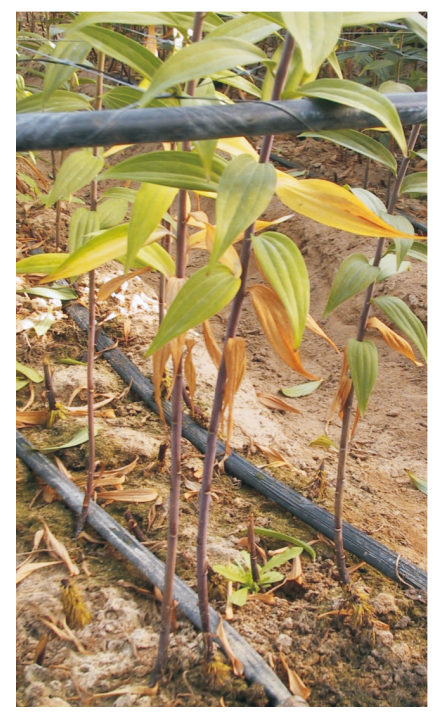

FIG. 1 - Chlorosis and defoliation of Oriental lily (cv. Tibet) plants naturally infected by Fusarium oxysporum f.sp. lilii. 


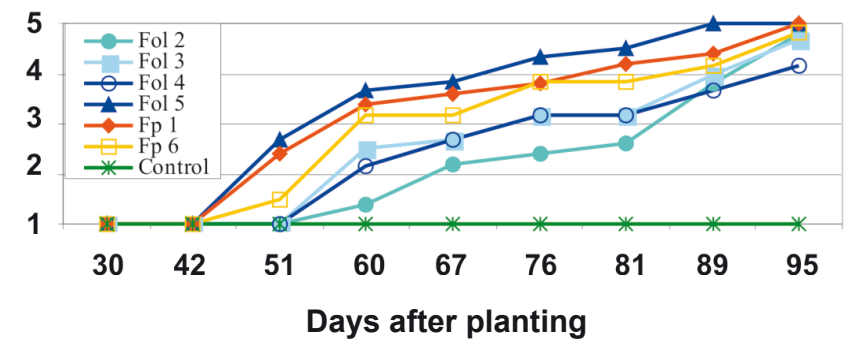

FIG. 2 - Progress of the severity of infections of lily bulbs (cv. Siberia) inoculated with isolates of Fusarium oxysporum and $F$. proliferatum.

\section{REFERENCES}

Bald JG, Paulus AO, Lenz JV (1983) Control of field root and bulb diseases of Easter lily. Plant Disease 67:1167-1172.

Löffler HJM, Straathof TP, Mouris JR, Baayen RP (1995). Durability of resistance in lily to basal rot: evaluation of virulence and aggressiveness among isolates of Fusarium oxysporum f. sp. lilii. European Journal Plant Pathology 102:261-271.

Recebido 10 Fevereiro 2006 - Aceito 16 Outubro 2007 - TPP 6015

Editores Associados: Francisco C.O. Freire

Wagner Bettiol 